\title{
The biopolitics of private conservation: jeopardizing labor and rhino to optimize capital?
}

\author{
Lerato Thakholi ${ }^{1}$ \\ Wageningen University, The Netherlands
}

\begin{abstract}
The conservation of biodiversity has increasingly been analyzed as biopolitical. That is, conservation initiatives such as breeding programs and protected areas seek to optimize some nonhuman life forms while exposing others to harm or degradation. Biopolitical conservation studies have looked at the implications of how human and non-human lives have been valued differently. Wildlife has received more attention than the lives of conservation laborers in studies of private conservation. The article builds on Foucault's conceptualization of biopolitics to dissect the responses of the eco-tourism and wildlife breeding industries to rhino poaching in the Lowveld, South Africa. There are two central arguments. First, their responses hinge on creating new and re-instating old avenues of capital accumulation that ironically prioritize the optimization of the wildlife economy over the lives of rhino. Second, I show that private conservation disproportionately exposes black laborers to harm while attempting to protect rhino from poachers, a function of how conservation labor has been governed since the onset of poaching in 2008. I conclude that private conservationists in South Africa make value judgments to construct a hierarchy of life with whiteness at its apex, rhinos following closely behind, with laborers, and finally poachers at the bottom.
\end{abstract}

Key words; Conservation labor, biopolitics, rhino horn, wildlife economy, South Africa

\section{Résumé}

La conservation de la biodiversité est de plus en plus analysée comme un phénomène biopolitique. En d'autres termes, les initiatives de conservation telles que les programmes d'élevage d'animaux sauvages et les zones protégées cherchent à optimiser certaines formes de vie non humaines tout en exposant les autres à des dommages ou à la dégradation. Les études de conservation biopolitique ont examiné les implications de la manière dont les vies humaines et non humaines ont été évaluées différemment. Dans les études sur la conservation privée, la vie sauvage a reçu plus d'attention que la vie des travailleurs de la conservation. Cet article s'appuie sur la conceptualisation de la biopolitique de Foucault pour disséquer les réponses des industries de l'écotourisme et de l'élevage d'animaux sauvages au braconnage des rhinocéros dans le Lowveld, en Afrique du Sud. Il y a deux arguments centraux. Premièrement, leurs réponses s'articulent autour de la création de nouvelles voies d'accumulation du capital qui, ironiquement, donnent la priorité à l'optimisation de l'économie de la faune sauvage sur la vie des rhinocéros. Deuxièmement, je montre que la conservation privée expose de manière disproportionnée les travailleurs noirs au danger tout en essayant de protéger les rhinocéros des braconniers, une fonction de la manière dont le travail de conservation a été régi depuis le début du braconnage en 2008. Je conclus que les défenseurs privés de la nature en Afrique du Sud portent des jugements de valeur pour construire une hiérarchie de la vie avec les Blancs à son sommet, les rhinocéros suivant de près, les travailleurs et enfin les braconniers au bas de l'échelle.

Mots clés: Travail de conservation, biopolitique, corne de rhinocéros, économie de la faune sauvage, Afrique du Sud.

\footnotetext{
${ }^{1}$ Dr. Lerato Thakholi, lecturer, Sociology of Development and Change, Wageningen University, The Netherlands. Email: lerato.thakholi "at" wur.nl. Acknowledgements: thanks to two reviewers, Bram Büscher, Stasja Koot and the participants at the Crisis Conservation workshop held from 5-9 October 2020. The workshop and the research for this article were made possible by an NWO-VIDI grant (nr. 425-14-001). This is the first article in Bram Büscher (ed.). 2021. "Political ecologies of extinction", Special Section of the Journal of Political Ecology 28, 696-888.
} 


\section{Resumen}

La conservación de la biodiversidad se ha analizado cada vez más como "biopolítica". Es decir, las iniciativas de conservación, como los programas de cría y las áreas protegidas, tratan de optimizar algunas formas de vida no humanas, mientras exponen a otras a daños o degradación. Los estudios sobre conservación biopolítica han analizado las implicaciones de cómo se han valorado de forma diferente las vidas humanas y las no humanas. La vida silvestre ha recibido más atención que las vidas de los trabajadores de la conservación en los estudios sobre la conservación privada. El artículo se basa en la conceptualización de Foucault sobre la biopolítica para diseccionar las respuestas de las industrias del ecoturismo y la cría de animales salvajes a la caza furtiva de rinocerontes en el Lowveld (Sudáfrica). Hay dos argumentos centrales. En primer lugar, las respuestas de estas industrias giran en torno a la creación de nuevas (y el restablecimiento de las antiguas) vías de acumulación de capital. Irónicamente, éstas priorizan la optimización de la economía de la fauna salvaje sobre la vida de los rinocerontes. En segundo lugar, muestro que la conservación privada expone de forma desproporcionada a los trabajadores negros a sufrir daños al intentar proteger a los rinocerontes de los cazadores furtivos. Esto es una función de cómo se ha gobernado el trabajo de conservación desde el inicio de la caza furtiva en 2008. Llego a la conclusión de que los conservacionistas privados de Sudáfrica emiten juicios de valor para construir una jerarquía de la vida, con la blancura en su cúspide, los rinocerontes siguiéndoles de cerca, con los trabajadores y, finalmente, los cazadores furtivos en la parte inferior.

Palabras clave: Trabajo de conservación, biopolítica, cuerno de rinoceronte, economía de la vida salvaje, Sudáfrica

\section{Introduction}

In South Africa, wildlife extinction fears over the last decade centered mainly on the Rhinoceros. This is exemplified by the chairperson of the Private Rhino Owners Association (PROA) in South Africa who stated in 2016 that:

...it is now time to stop talking and carry out bold actions to save one of the most iconic species in the world. If not, the negative impact on our image as a country - the loss of a species and no longer being home to the Big Five - is beyond comprehension. ${ }^{2}$

These fears are compounded by the fact that some genetically unique rhino populations in Africa have already gone extinct (Moodley et al., 2017). Consequently, violent interventions conceptualized as 'war' on poaching have resulted. These have been referred to as 'conservation' (Duffy 2016), 'green militarization' (Lunstrum, 2014), 'green violence' (Büscher and Ramutsindela, 2016), and more broadly as 'green wars' (Büscher and Fletcher, 2019). The aim has been to secure nature reserves, keep poachers out, and maintain viable rhino populations. These life and death decisions about which species to wage 'war' for, are always value-laden (Biermann and Anderson, 2017). As a result of this, conservation of biodiversity has been conceptualized as biopolitical (Cavanagh, 2014; Fletcher, 2010) because it exercises "power to make live and let die" (Foucault, 2003: 241) at a population level. By using a biopolitical lens, the article contributes to these analyses by investigating how interventions to protect rhino mask a hierarchy of life inherent in conservation efforts.

Cavanagh (2014: 273) identifies three main axes along which biopower has been exercised. These are

...between differently 'racialized' populations of humans; second, between asymmetrically valued populations of humans and nonhumans; and, third, between humans, our vital support systems, and various types of emergent biosecurity threats.

\footnotetext{
2 https://www.rhinoalive.com/wp-content/uploads/2016/06/PelhamJones2.pdf last accessed 10 May 2021
} 
In conservation research, there have been a plethora of studies primarily exploring the second axis. These includes Lunstrum (2018: 1023), who argues that capital-enabled green militarization in Southern Africa shores up state power over landscapes and "flags a biopolitics in which the state is better able to intervene in and act in the name of life and death, that is of protecting rhino life even if this means taking the life of the poacher." Likewise, Cavanagh and Benjaminsen (2015) explore the various ways farmers on Mount Elgon in Uganda resist the biopolitical implications of conservation efforts that infringe on their food security. Protected areas are thus spaces where value judgments are made about which life forms to foster, and which to ignore and which to exterminate, to 'optimize' life on ecosystem and population levels (Biermann and Anderson, 2017).

This article focuses on the biopolitics of conservation along the first two axes that Cavanagh (2014) identifies because they have been the most prevalent in rhino conservation. It does so by dissecting how biopower is employed in conservation because despite the proliferating literature, few studies explore "the different ways in which biopower can be exercised" (Fletcher et al., 2019: 1070). The exercise of biopower is, following Fletcher (2010) and Agrawal (2005), often identified as 'environmentality', understood as a mode of environmental governance that can be deployed in the application of biopower. Fletcher distinguishes four such environmentalities - truth, sovereign, disciplinary and neoliberal. This article focuses on the latter two because they are most illuminating for the analysis. Disciplinary environmentality entails the internalization of ethical social norms which individuals adapt to (Fletcher, 2010). Neoliberal environmentality, on the other hand, is informed by neoliberal market logics including "increasing involvement of private sector actors, displacement of public policy by market mechanisms, uptake of environmental valuation methodologies, and commercialization and privatization of resource management institutions" (Bakker, 2005: 542). The wildlife economy discussed here exemplifies these modes of governance through the normalization of privatization, commercialization and commodification of natures, including rhino (horn).

Two central foci drive the discussion. First, the article discusses interventions that have been initiated to protect rhino from extinction. Rhino poaching in South Africa increased significantly between 2008-2015, making it the biggest conservation issue in the country, accompanied by a suite of interventions to ensure their survival. These include, besides the above-mentioned 'green militarization' of parks, the legalization of domestic trade in rhino horn, dehorning and the relocation of rhino from South Africa to Botswana. The argument in favor of these interventions is simple: conservation organizations believe they need to employ every tool in their arsenal, including violent force if necessary, to save rhino (and other species) from extinction. I analyze these interventions as biopolitical because they are meant to make rhinos live. However, this article argues that interventions to protect rhino from extinction ironically prioritize the profitability of the wildlife economy through the creation of commodities such as horn and the creation of luxury tourism (Koot, 2021).

Second, it analyses the disciplinary and neoliberal environmentalities governing conservation labor that arise out of, and are reinforced by, this focus on the profitability of the wildlife economy and its fight against rhino poaching. To dissect this, I borrow from Lorenzini (2021: 43) who reminds us that biopolitics "is a politics that structurally relies on the establishment of hierarchies in the value of lives, producing and multiplying vulnerability as a means of governing people", including through labor (Negri, 2008). Through job incentives, polygraphing of labor and interventions such as environmental education, I show how private nature reserves govern their labor force in the interest of protecting rhino and wildlife. Furthermore, by discussing the socioeconomic conditions in laborer's homes, I highlight the 'let die' conditions that black conservation workers are exposed to. This includes infrequent access to drinkable water and infrastructural decay all of which are necessary for survival. I argue that through non-intervention, black conservation labor is disproportionately exposed to harm.

Comparing rhino to conservation labor might seem crude, perhaps. But the point is to show the complex value judgements inherent in conservation. The article thus seeks to problematize what has essentially become the norm in South African conservation spaces. That is: by intervening in (protecting) rhino life and not intervening in the lives of black labor, conservation renders rhino lives more valuable than black lives. There is, however, a notable contradiction here, because the value most important in practice is 
not intrinsic, but the financial value of rhino. Ironically, this focus on financial value has the - perhaps inadvertent - effect of prioritizing the profitability of private capital through new commodities and consumption over the actual lives of rhino. I will conclude that this contradiction exposes not just an implicit hierarchy of life from whites via rhinos to conservation labor, but also a capitalist conservation industry at odds with itself (See Büscher et al., 2021).

The analysis is based on 15 months of ethnographic research on the private conservation sector, with a particular focus on three events that I attended in South Africa between 2016-2019. First, the Convention on International Trade in Endangered Species of Wild Fauna and Flora (CITES) hosted by South Africa between 24 September-5 October 2016. This was the 'rhino CITES', as the South African government used the opportunity to highlight the then ongoing rhino-poaching crisis. Given that rhino poaching was such a big issue, many actors in the 'rhino space' attended the event to present their positions. The event was attended by over 3,500 people from across the world. The second event was Wildlife Ranching SA (WRSA) annual conference on 23-24 March 2018. WRSA represents the interests of over 2,000 commercial wildlife ranching stakeholders involved in game breeding, tourism, hunting and game products. This makes it one of the biggest of its kind in South Africa. The event was titled Expand your Game, pointing to the fact that the sector was looking to expand and diversify its product offering. The last event was a game auction on 9 June 2018 hosted by Bloodline Africa, an "auction group, consisting of eight different breeders" ${ }^{3}$ from different parts of South Africa. Bloodline Africa hosts an annual auction that brings together stakeholders and investors interested and involved mainly in wildlife breeding. In 2018, the event was attended by over 300 stakeholders with 98 lots of 276 animals on auction. Conference brochures and presentations were collected, and I took notes which I later analyzed. Altogether, these event ethnographies gave me insights into the private wildlife economies responses to rhino poaching. In addition to the events, I conducted interviews with 70 people working in the conservation sector such as NGOs, breeders, and general workers in the Lowveld, South Africa.

In what follows, I first outline the conceptual framework which brings together biopolitics and environmentalities. Following this, I discuss various interventions against rhino poaching and the multiple environmentalities governing conservation labor. I conclude by arguing that private conservationists in South Africa make value judgments to construct a hierarchy of life with whiteness at its apex, rhinos following closely behind, with black laborers and finally poachers at the bottom.

\section{Biopolitics and environmentality}

As mentioned, biopolitics entails continuous value "judgements about what forms of life need to be supported and what forms not" (Büscher, 2018: 150). It is power exercised over populations (Fletcher et al., 2019) such that - in conservation - "individual lives acquire meaning only when they advance the long-term well-being of the broader population or are essential to sustaining key biological processes, especially evolution" (Biermann and Mansfield, 2014: 264). While Foucault (2003, 2008) conceptualized biopower in relation to the governance of people, there has recently been a mushrooming of scholarship applying this lens to non-human lives, including for the conservation of biodiversity (Cavanagh and Benjaminsen, 2015).

Conservation of biodiversity is biopolitical because it is preoccupied with "making nature live" [emphasis in original] (Bierman and Mansfield, 2014: 258). This happens "through habitat protection and the maintenance of viable population numbers of species in the wild, as well as through technologically assisted reproduction, the cryogenic storage of DNA, and the cloning of endangered or even extinct nonhuman species" (Heatherington, 2012: 53). Political ecologists have mobilized Foucault's conceptualization of biopower to study these interventions at various scales and in different constellations within and between human and non-human lives (Cavanagh, 2018). In their review, Biermann and Anderson (2017) aggregate biopolitical conservation along four lines: endangered species management, conservation breeding and genetics, protected areas, and rewilding. They suggest that there is no universal conservation biopolitics, but that there are different, interrelated and competing techniques bearing down on lives in both complementary

\footnotetext{
${ }^{3}$ https://www.bloodlineafrica.com/about-us last accessed May 2021.
} 
and contradictory ways. Of interest here is how interventions against rhino poaching obscure the value judgements informing which life forms are exposed to vulnerabilities and which ones are allowed to flourish.

Conservationists, the state and scientists, but also private capital, regularly make decisions about which human and non-human lives to prioritize and which to let die (Biermann and Mansfield, 2014). The life-or-death decisions that result are value laden and increasingly infused with market logics - so developing a neoliberal biopolitics that is more interested in supporting economic growth than life per se (Fletcher, 2010). Crucial within any biopolitics, including of the neoliberal kind, is the collection of scientific knowledge about species. This knowledge, Chernala (2012) argues, is often used not for altruistic reasons but to improve the use-value of species to humankind. In the wildlife economy, this is exemplified by wildlife breeders who rely on bio-information to breed animals with bigger horns or color variants for maximum profits. Breeding thus "involves the biopolitical management of lineages, reproductive practices, and bodily and genetic forms" (Biermann and Anderson, 2017: 5).

In the analysis of conservation as biopolitics, the focus has thus far mainly been on nonhuman lives. Studies that have explored human lives have tended to look at communities living next to newly established protected areas or indeed at poachers (Lunstrum, 2018). The people who work in these landscapes are often left out of these analyses. To start thinking through this, I take inspiration from recently published work related to labor during the COVID-19 pandemic. Commenting on how frontline workers and the working poor have been treated during the pandemic, Rose (2021: 215) states that "the question of who will be made live and who will be let die falls along existing lines of social and political inequality, at multiple geographic scales." Following from this, the differential exposure to vulnerabilities because of rhino poaching is likely to be distributed along pre-existing racialized divisions of labor in conservation. This is because biopolitical power creates a hierarchy in 'the human order', often along racial lines (Lorenzini, 2021).

To analyze how biopower is exercised over wildlife and conservation labor, it is useful to introduce the term environmentality, which above I defined as a mode of environmental governance that can be deployed in the exercise of biopower. Fletcher $(2010,2017)$ follows Foucault, to distinguish the four different environmentalities outlines above. Disciplinary and neoliberal environmentalities highlight the contradictions inherent in the governance of rhinos and conservation labor. According to Fletcher (2010: 173),

While a disciplinary environmentality operates principally through the internalization of social norms and ethical standards to which individuals conform due to fears of deviance and immorality, and which they thus exercise both over themselves and one another, a neoliberal governmentality seeks merely to create external incentive structures within which individuals, understood as self-interested rational actors, can be motivated to exhibit appropriate behaviors through manipulation of incentives.

Neoliberal environmentality in conservation is a mode of governance dominant in what has been termed neoliberal conservation, which is characterized by uneven development, privatization, and the commodification of natures which cumulatively function to expand capitalism's reach through natures (Büscher and Arsel, 2012; Castree, 2003, 2008). The wildlife economy in South Africa has been characterized by neoliberalization, so it is logical that the responses to poaching will also be governed by similar principles.

The importance of using the environmentalities approach is that it renders explicit how value decisions are made in practice and with what objective in mind. Hence, it allows us to understand biopolitics in practice, which I will employ to analyze rhino conservation and how modes of environmental governance in response to the threat of poaching creates an implicit (and often very explicit) hierarchy of life. 


\section{Rhino conservation versus the wildlife economy?}

To suggest that responses against wildlife crime are biopolitical is just the beginning of an analysis to unearth the multiple values informing these interventions. Others have outlined the history of the development of the private wildlife economy (Carruthers, 2008) and rhino conservation (Emslie and Brooks, 1999). What I will do here is to explore the various interventions and the rationalities they present. To do so, it is important to briefly contextualize wildlife ownership in South Africa. Due to policy provisions, wildlife can be owned privately in South Africa (see Snijders 2015). Though numbers are difficult to ascertain, it is estimated that $49 \%$ of white rhinos (Ceratotherium simum) are privately owned (Emslie et al., 2019) and traded through live sales, trophy hunting, ecotourism, and game products (Crookes and Blignaut, 2015). Thus, when poaching numbers started skyrocketing in South Africa in 2008, private rhino owners were also affected. These farmers and owners are part of the broader private wildlife economy which includes breeding, hunting, nature-based tourism, and game meat production, amongst others. Below, I discuss responses from the nature-based tourism sector and wildlife farmers. While opinions about the best intervention are diverse, there has been a general trend towards eco-tourism commodities and the (re)commodification of rhino horn as a solution.

\section{"CITES has highly endangered rhino"}

These are the words of a private rhino owner and breeder who also stated that "if legalization of trade would happen, I would have nearly unlimited money to protect my rhino". ${ }^{4}$ These statements were in 2017, and this breeder also expressed discontentment with the Department of Environment's stance on the legalization of trade in rhino. A few decades back in 1977, the Convention for International Trade in Endangered Species (CITES) listed black and white rhinos in its Appendix I, which prohibited the trade in rhino and their parts globally (Biggs et al., 2013). This was in response to years of poaching that had decimated rhino populations in the wild. Through the Natal Parks board rhino relocation program, however, rhino numbers increased significantly ('t sas-Rolfes, 1990). Accordingly, in 1994 white rhino were moved to Appendix II of CITES, which enabled the export of trophies and the trading of some animals. However, when poaching increased dramatically a decade later, the Minister of Environment in South Africa placed a moratorium on the domestic trade in rhino horn in 2009. Despite the moratorium, poaching numbers continued to soar such that by 2014 more than 1,000 rhinos were being poached annually in South Africa (though those numbers started declining again from 2016 onwards).

Citing the failure of the 1977 CITES ban, private rhino owners in South Africa launched a campaign to legalize trade in rhino horn. They argued that the CITES trade ban had inadvertently increased illegal trade. In fact, rhino populations continued to plummet despite CITES and the 2009 moratorium (Hübschle, 2016). Rhino owners argue that "a legal trade in rhino horn (in which not a single animal would need to be killed) would enable the government to free up substantial funding for many other conservation priorities as rhinos would have a real value and pay for their security". ${ }^{5}$ The overall sentiment, as expressed above, was that by legally and physically separating rhino from their horns, a rhino would literally pay for its place in the ecosystem. Thus, the South African Private Rhino Owners Association (PROA) organized an international campaign to influence CITES to allow for trade that gained the support of countries like Swaziland. This campaign failed, and the international ban remained. However, in 2017, the South African moratorium on domestic trade in rhino horn was lifted and rhino horn was legally re-commodified nationally.

Proponents of legal trade recognized that certain conditions such as curbing laundering and corruption would need to be met, in order to make legal wildlife trade viable (Biggs et al., 2013). However, these conditions were not met before South Africa legalized domestic trade. Commenting on the South African constitutional court's decision to legalize trade in 2017, Collins et al. (2020) suggest that the decision fell short because it was not informed by a transdisciplinary understanding of the crisis. Furthermore, echoing the International Rhino Coalition's (2014) findings, they argue that this could increase the extinction rate of

\footnotetext{
${ }^{4}$ Interview, Rhino breeder, 6 September 2017.

${ }^{5}$ Wildlife Ranching magazine, Rhino Supplement https://www.rhinoalive.com/wp-content/uploads/2016/06/RS_MavusoMsimang-DPS.pdf. Last accessed 25 May 2021.
} 
rhinos because legal horn could be laundered into an illegal international market. Hübschle (2017) shows that this is already happening within the private sector because some horn from legal hunts and pseudo-hunts enters the illegal market. She states that:

...to the rogue wildlife professional (used as an umbrella term here), the contestation of the [CITES] ban also relates to the valuation of rhino horn as a highly profitable commodity. The intrinsic value of the rhino as a wild animal worthy of protection for the common good is secondary in this instance. In borrowing from the conservation discourse that portrays private ownership of rhinos as a conservation strategy, the rogue wildlife professional legitimizes his or her illegal economic activities in terms of contributing to conservation. (Hübschle 2016: 292, emphasis added)

Thus, while proponents of legal trade suggest that it will augment security costs and in turn help protect rhino from extinction, it seems that the monetary returns from legal trade prioritize the financial value for the private rhino owners over the intrinsic value of rhino themselves. This is affirmed by Eikelboom et al. (2020) who suggest that legalizing trade in horn would have adverse implications for wild rhinos but would benefit private rhino owners through increased revenue. Furthermore, while not advocating for or against trade, Taylor et al., (2017) suggest that legal trade could incentivize more farmers towards financially lucrative intensive breeding, and they suggest an implication of this might be a decline in wild rhino populations. Having said that, private rhino owners have incurred significant security costs. Furthermore, between 2007-2018, there was a 67\% drop in the value of white rhino (Emslie et al., 2019). A common adage at the time became 'a rhino is worth more dead than alive.'

In addition, 28\% of private rhino owners surveyed by Clements et al. (2020) sold a percentage of their rhino. Yet, in an article aptly titled "a new investment frontier", the chairperson of PROA states that "investors in search of new investment frontiers are now in a position to consider the previously illegal and therefore inaccessible market of rhino-horn". ${ }^{6}$ The speculative nature with which the domestic trade in rhino horn has been approached coupled with the fact that much of the institutional shortcomings have not been dealt with, and that there is virtually no consumption of rhino in South Africa, suggests that the legalization of domestic trade in rhino horn serves to amplify private capital, not rhino populations in the wild.

Related to the legalization of domestic trade in rhino is dehorning. Initially hailed as a deterrent the method has since come under fire mainly from rangers, who note that "dehorning does not stop poachers, whatever they get out of the stump might be enough for them" ${ }^{7}$. Furthermore, a warden explains "if poachers track a dehorned rhino, they will kill it just so that they don't have to track it the next day". ${ }^{8}$ However, some reserves continue to dehorn suggesting that as a deterrent, the method does work. Either way, a harvested horn is a valuable commodity.

\section{Rhino relocation}

In addition to the legalization of domestic trade in rhino horn, there has been a whole host of interventions from the nature-based tourism sector aimed at curbing poaching. One such example is the private sector-organized rhino relocation program from South Africa to Botswana which was meant to expand the rhino range and protect them within Botswana's controversial shoot-to-kill landscape (which has since been abolished). Analyzing this initiative, which has involved the likes of Hollywood's Uma Thurman, Koot $(2021,4)$ argues that these types of initiatives "are based on a reductionist articulation of the rhino poaching crisis, de-politicizing it from its socio-economic and historical context while legitimizing privatized, luxurious tourism and pushing exorbitant consumerism as a solution for social and environmental

\footnotetext{
${ }^{6}$ https://www.rhinoalive.com/wp-content/uploads/2018/06/Rhino-files-SP.pdf last accessed 25 May 2021

${ }^{7}$ Interview, Ranger Hoedspruit, 23 March 2018.

${ }^{8}$ Interview, Warden Hoedspruit, 30 May 2018.
} 
crises." In addition to fostering forms of consumption, a veteran ranger noted that these policies tend to aggravate poachers more than anything else $^{9}$, although industry opinions differ widely on this issue.

There are two points to make from this. First, as with the legalization of domestic trade in rhino horn, the relocation program purports to be in the interest of rhino populations. However, as Koot (2021) notes, these initiatives further the economic interests of the private wildlife economy by legitimizing conspicuous consumption. Second, this affirms Fletcher's (2010) observation that states, and capital can employ multiple environmentalities to 'save', in this case, rhino populations. That is, Botswana's former shoot to kill policy was the epitome of sovereign power, the power to take life. Yet simultaneously, it facilitates a neoliberal environmentality, focused on capital growth within the wildlife economy.

In addition, there have been a plethora of activities including 'running for rhino', 'golfing for rhino', 'dancing for rhino', and a whole host of rhino-related products, all with the aim of intervening in the rhinopoaching crisis by collecting money for anti-poaching initiatives. While these interventions arguably do not harm rhino physically, they certainly have capitalized on the crisis. Whereas rhino farmers and the naturebased tourism industries' interventions have been widely different, they are both based on a neoliberal logic that prioritizes the demands and needs of the private wildlife economy over the intrinsic value of rhino. To see how this compares to how black conservation laborers are governed, I zoom into the Lowveld landscape which is the center of one of the biggest wildlife economies in South Africa. The area has nature-based tourism and wildlife farming, and both have participated in some of these interventions.

\section{Environmentality and collective labor}

The Lowveld landscape is spatially and socio-economically unequal with some sections, especially in the north, dotted by a mosaic of private nature reserves around a small-town called Hoedspruit in the Maruleng municipality. In the south, there is Acornhoek in Bushbuckridge municipality, which is a former apartheid homeland. Here, there are many social issues such as high unemployment, lack of water and poor health facilities, while it is also home to many conservation laborers.

Some conservation laborers live on the private nature reserves for 21 days and in return get 7 days off. Others still commute from Bushbuckridge to the private nature reserves every day. The respondents quoted below worked in anti-poaching, housekeeping and maintenance, and some were rangers. This section compares how black lives, especially laborers and their families, and wildlife, in particular rhino, have been valued. This might appear crude, yet when an antipoaching agent in an interview states that "for the landowner, the lion or rhino or whatever wildlife is more valuable because that's how they make their money" there is an urgent reason to flesh out how this materializes in these landscapes. The agent further observed that "for my employer, they value my life because again that is how they make their money, through my work". ${ }^{10}$ This comment captures the value judgments central to the conservation of biodiversity. These judgments are concealed by interventions such as those discussed in the previous section. To underscore this, I will illustrate and elaborate on the disciplinary and neoliberal environmentalities governing conservation laborers.

\section{Neoliberal environmentality (jobs as incentives)}

When probed about the implications of rhino poaching, some conservation laborers stated that "the poaching is an issue because guests from far away expect to see the rhino. When we lose the Big Five, we will also lose jobs". ${ }^{11}$ In this sense, laborers suggest that the survival of rhino is directly tied to their employment. Whether the extinction of rhino would crash the South African tourism sector is questionable. However, there is a clear incentive for laborers to ensure that rhino and wildlife more generally are protected because their livelihoods currently depend on them. Public officials in Bushbuckridge and Maruleng also noted the employment opportunities that private nature reserves offer in areas with $64.6 \%$ and $51.2 \%$

\footnotetext{
${ }^{9}$ Interview, Ranger Hoedspruit, 21 March 2018.

${ }^{10}$ Interview, anti-poaching agent, Acornhoek, 14 May 2018.

${ }^{11}$ Interview, laborer, Acornhoek, 4 March 2018.
} 
unemployment rates respectively (StatsSA, 2021). Because conservation laborers come from communities with such high unemployment rates, they would be intimately acquainted with the effects of unemployment. In fact, when pressed upon the most urgent issues in their communities, conservation laborers often mentioned unemployment, suggesting that high unemployment figures were more than just numbers to them. As a guide explained, "poaching affects us because if all the animals are killed then we are out of jobs". ${ }^{12}$ Jobs as incentives are prolific in conservation development, however, as Wieckardt et al. (2020) show, these employment opportunities can exacerbate social stratification in communities by employing people who are already well-positioned to secure work as guides, for example.

In the Lowveld, 'jobs as benefits' comes directly from private nature reserves whose owners and managers frequently cite job creation for locals as a benefit. In addition, many often note the socioeconomic challenges in neighboring communities. One reserve stated that:

...the majority of our staff come from the surrounding local communities, so we see it as our duty to do our best to make a positive contribution, especially with the needs that are continually evident within such a rural setting. ${ }^{13}$

Some of these jobs are permanent while others are temporary bush clearing or construction jobs. As another reserve notes:

The proposed extension [...] will benefit the local communities in terms of employment opportunities and job creation. It is estimated that approximately 65 jobs will be created during the construction phase and 18 jobs during the operational phase. Skills development and training will also be a benefit. $100 \%$ of this labour will be sourced from previously disadvantaged individuals from the local communities. ${ }^{14}$

With unemployment rates so high, nature reserves do create jobs. However, talk about local 'participation' and 'benefits' often mask the fact that conservation also needs labor, and that this labor is crucial for private capital (Neimark et al., 2020; Thakholi, 2021). That said, it is important to dissect what these jobs entail. As the previous quote suggests, some of these jobs are temporary, while permanent jobs are characterized by poor labor conditions. For instance, I met general workers in a game reserve earning as little as US\$190 per month, a salary which many respondents were dissatisfied with. This was compounded by difficult working conditions including unpaid overtime, sub-par accommodation, and racism in the workplace.

Furthermore, for many, the prospects of getting a promotion are limited as evidenced by some older laborers who had been working in housekeeping and maintenance for over ten years. Consequently, when a laborer states that "the best promotion I can get from this position is to become a poacher". ${ }^{15}$ it is a reminder that conservation does not have a monopoly over the neoliberal biopolitics of rhino conservation. As Hübschle (2016) notes, a ranger can be offered ten times more than their salary to simply point at the location of rhino. Notwithstanding what is clearly a lucrative deal, and despite unfavorable working conditions, many workers do not become informants, otherwise rhino would be far worse off. The simple issue here is that private conservation uses the promise of jobs and other technologies to conserve rhino.

\footnotetext{
12 Interview, guide, 19 February 2017.

13 https://www.thornybush.com/ last accessed 1 June 2021.

${ }^{14}$ http://www.nuleafsa.co.za/wp-content/uploads/2018/09/Draft-BAR-Kapama.pdf last accessed 1 June 2021.

${ }^{15}$ Interview, security, 16 February 2017.
} 


\section{Disciplinary environmentality}

In addition to external incentive structures meant to motivate conservation laborers to protect wildlife, private nature reserves use various technologies on workers "to ensure that all the workers are clean"16 as one ranger elucidated. That is: to ensure that there are no poachers within the organization. These include layered voice analysis for new employees and occasional polygraphing. The latter was implemented after multiple cases of nature reserve employees from casual laborers to management being implicated in poaching. Thus, polygraphing was set in place by private game reserves to 'weed out' employees who have participated in or have knowledge of poachers. There are at least two companies in Hoedspruit offering the service (Figure 1). Most conservation laborers, including housekeeping, maintenance, rangers and anti-poaching agents were subjected to a polygraph test at least twice.

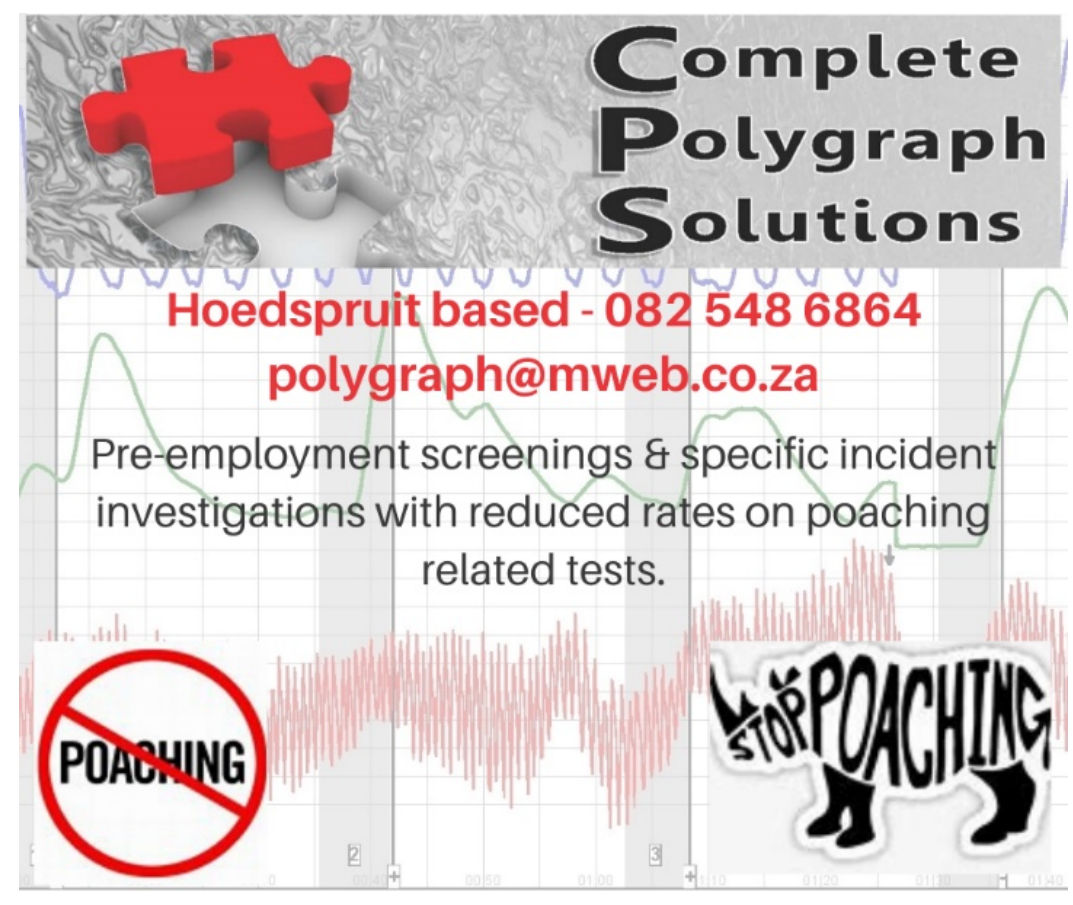

Figure 1: Advertisement for a polygraphing company operating from Hoedspruit. Sourced from their Facebook page. ${ }^{17}$

Labor law in South Africa allows for the use of polygraphing by an employer with the written consent of an employee. However, the results alone cannot be used as grounds for dismissal ${ }^{18}$ because they are not conclusive. Despite this, a trainer noted that some rangers had been fired for suspicion of selling information about rhino because "it doesn't necessarily mean that they [a laborer] sent the text, but if they have knowledge of anyone else who did, like a family member, they will fail the test". ${ }^{19}$ Polygraphing, as an employee mentioned "has made the working conditions very hard because we are always stressed. You do not know when you are going to get fired". ${ }^{20}$ This technology has created an environment where workers

\footnotetext{
${ }^{16}$ Interview, Ranger, 23 March 2018.

17 https://www.facebook.com/626995510696122/photos/a.2420473414681647/3167282570000724/?type=3\&theater Last accessed 5 June 2021.

${ }^{18}$ https://www.ccma.org.za/Advice/Information-Sheet. Last accessed 25 May 2021.

${ }^{19}$ Interview, 22 November 2018, Hoedspruit.

${ }^{20}$ Interview, 4 March 2018, Acornhoek.
} 
internalize a sense of insecurity and fear of dismissal which in turn forces them to police not just themselves but the people around them as well.

Many laborers claimed that some colleagues had been fired based on their test results. This was vehemently denied by a manager in a private nature reserve who mentioned that the questions posed were direct and if an employee failed the test, they were investigated further. What is undeniable is that polygraphing is a disciplinary technology that is used to ensure that rhinos are not poached, while conversely threatening black workers with the social reproductive risks associated with unemployment. This technology works on the individual worker who, upon failing the test, can be fired. However, the real target as the ranger above stated, is the labor force more generally. That is, the polygraph tests are used on individual labor to ensure that the collective labor force is vitalized in the service of protecting rhino and enabling neoliberal conservation. The biopolitical nature of polygraphs is captured by Complete Polygraph Solutions (Figure 1) who state that:

...once someone is employed, it is advisable for employer's to periodically test their employees. This serves a dual purpose. On the one hand the employees are made aware that their actions are monitored on a regular basis, resulting in hesitance to commit any undesirable acts. $^{21}$

There is an inherent contradiction here, which Labban's (2014) analysis on the sovereign power of capitalism helps to untangle. He notes that layoffs in oil companies show the contradiction of capital, "which exposes certain workers to death at the same time that it seeks to improve the workers' chances of life through safety boards, routines and regulations intended to eliminate hazards, prevent accidents and enforce safety standards" (Labban, 2014: 491). Thus, while the consequences of unemployment expose some to harm, workers that pass the test through working in an environment saturated with mistrust can continue to protect rhino and meet their social reproductive needs. The biopower of private conservation is therefore expressed in the ability to subject some laborers to unemployment in order to improve the collective force, save rhino life and uphold the (profitability of the) wildlife economy more generally. However, polygraph tests are new and have been ushered in under exceptional circumstances. As Lorenzini (2021:42) notes, by focusing on extraordinary circumstances, like COVID-19, "we risk overlooking the fact that disciplinary and biopolitical power mainly functions in an automatic, invisible, and perfectly ordinary way-and that it is most dangerous precisely when we do not notice it." For this reason, I turn to ordinary scenarios that reveal how laborers internalize environmental protection.

The conservation laborers I spoke to hold a range of ideas about environmental protection. However, a sentiment that was echoed many times was that "wild animals should be protected because future generations have to see them". ${ }^{22}$ This way of framing environmental governance is not endemic to private nature reserves in the Lowveld but has become the norm globally. Thus, by suggesting the importance of rhino for future generations, conservation laborers demonstrate the internalized environmental values that have become commonplace in conservation. This is not to suggest that laborers do not value wildlife. Rather, and given that very few people from laborers' homes have ever set foot in a private nature reserve, it begs the obvious question: for which future generations should wildlife be preserved? Upon further probing it became apparent that laborers' conceptions of environmental problems did not immediately feature wildlife. Rather, laborers identified lack of access to water, unemployment and bad roads as the most pressing issues in their immediate environments. I will return to this shortly.

A description of the plethora of environmental initiatives that private nature reserves host in neighboring villages might help contextualize why a conservation laborer would frame their response in that manner. At least six private nature reserves along the border of the Kruger National Park close to the communities organize various environmental programs. These include vegetable gardens, conservation

${ }^{21}$ https://apotgiete0.wixsite.com/polygraph/contact . Last accessed 23 May 2021.

22 Interview, 4 March 2018, Acornhoek. 
awareness, environmental education, health programs, and soccer tournaments. These initiatives target youth, the elderly, school children, and orphans. One nature reserve that hosts an annual workshop for the children of its employees' notes "by establishing a love for nature and conservation from as early an age as possible, we inspire these children and their families to adopt a way of life that protects their environment" 23 [italics added]. Problematic language aside, the reserve has hosted 25,500 participants to these workshops. Under an aptly titled section called 'Incentives' it lists gifts such as school uniforms and Christmas presents for the local communities. This is just one organization amongst others that run programs in villages that emphasize instilling a supposedly absent love for the environment in local residents. By adopting this dominant view of the environment, conservation shapes the conduct of laborers and their families.

Private nature reserves run these programs to create Agrawal's conceptualization of "environmental subjects - people who care about the environment" (2005: 162). In addition to these programs, Pastor Mpho, a local priest in Acornhoek was invited to a workshop in a private reserve, where pastors were told to preach about poaching problems. Following this, Pastor Mpho started to preach anti-poaching to his 25 congregants. Considering all these environmental programs are meant to 'establish a love for nature', some conservation laborers are bound to internalize a particular way of thinking about the environment. Hence, environmental education is exemplary of a disciplinary environmentality (Fletcher, 2010).

\section{Letting die}

Nature reserves combine disciplinary and neoliberal environmentalities to govern laborers such that they are both incentivized to protect rhino and have internalize moral standards about environmental protection. Both serve to maintain a labor force that is vitalized in service of wildlife, and neighboring communities that are amenable to in situ preservation. However, by looking within and beyond the fence into communities where workers come from, the 'let die' of conservation is revealed. To work this out, I follow Marcatelli \& Büscher's $(2019,761)$ reminder that "'letting die' is not about 'killing' people - as some mistakenly understand the concept - but about the disinvesting or non-intervening in particular groups of people (or 'forms of life') so that these have structurally less chance of making a living or more chance of seeing their livelihood wither." The 'non-intervening' implicates conservation organizations, local municipalities, and the Department of Environment. The latter has spearheaded some interventions discussed in the previous section. However, the Department rarely if ever makes mention of the working conditions of conservation laborers. If anything, the Department of Environment also champions 'jobs as benefits' without questioning the quality of jobs the sector offers to locals.

In addition, due to the racialized division of labor in conservation, black laborers in general are disproportionately exposed to life-eroding circumstances such as subpar housing but also death itself. This is evidenced by one reserve in the Lowveld where low-wage, predominantly black workers are expected to walk a $2 \mathrm{~km}$ stretch from the main gate to the reception in an area which has large mammals and predators. Though the reserve has plenty of game drive cars, twice a day, day staff walk the stretch of road to and from the bus. On one occasion a female laborer would have been attacked by a leopard had a car not driven by. ${ }^{24}$ Similarly, in another game reserve, a security guard lamented that:

...sometimes we carry guns, other times we don't [...] we are not even allowed to shoot at an animal if it charges at you, even if it's about to kill you are not allowed to shoot it. You have to find other ways to escape. Only poachers can be killed, not animals. ${ }^{25}$

In view of the findings of the previous section where I pointed to the monetary value of wildlife, it is perhaps unsurprising that private landowners would rather have an employee sustain some injuries as opposed to losing their expensive commodity. This quote also shows the sovereign and neoliberal environmentalities of

\footnotetext{
${ }^{23}$ https://www.ecochildren.co.za/our-projects/eco-education

${ }^{24}$ Personal fieldnotes, 20 February 2017.

${ }^{25}$ Interview, security, 18 February 2017, Hoedspruit.
} 
conservation which works on poachers and laborers respectively. From this, it is evident that racism and biopower are inextricably linked because the former orders human groups based on differential exposure to vulnerability (Lorenzini, 2021).

The vulnerabilities are also observed by laborers who mentioned unemployment, lack of water and bad roads as some of the most pressing issues in their villages. As mentioned, the unemployment rates are very high in Bushbuckridge, well above the (already high) national average. Furthermore, conservation laborers and the communities they come from barely have consistent access to clean drinkable water. Only 8.3\% of residents have piped water in their residence (StatsSA, 2021), the rest depend on communal taps which have an infrequent supply of water. Observing a business opportunity, some wealthier families have dug boreholes and now sell water to community members. Others, who own pickup trucks, run a water delivery service where community members can pay per trip. Water is essential for human reproduction; failure to provide it exposes communities to vulnerability (Marcatelli and Büscher, 2019).

The third concern that workers mentioned were bad roads. Having driven the Acornhoek main road multiple times, I can attest to the gaping potholes, patches of tar and mud flows when it rains. The nonintervention in infrastructure has far-reaching implications for the community at large. Good infrastructure, including road networks is known to attract investors who would in turn provide jobs. Furthermore, at present, businesses and homes along the road tend to flood due to poor or non-existent stormwater drainages. The material implications of the municipality's failure to provide this service are far-reaching. Yet across the fence in nature reserves, multiple interventions are set in place to ensure that rhinos are protected, including intervening in the collective labor force.

\section{Conclusion: making landscapes live}

In light of the above considerations, I argue that private conservation adheres to a hierarchy of life in which rhino are rendered more important than black conservation labor. This hierarchy is informed by market principles because, though rhinos are fiercely protected, the interventions discussed give precedence to the monetary returns of the private wildlife economy over the intrinsic value of rhino themselves. Similarly, the interventions in laborers lives create a workforce that can render just enough labor to keep the wildlife economy functioning while simultaneously disallowing life in the former apartheid homelands. This is shortsighted and indicative of capitalism's contradictions, including undermining the material base of accumulation itself (Harvey, 2014).

The disproportionate investment in rhino life compared to other wildlife underscores why claims of intrinsic value are questionable. If all wildlife has intrinsic value, proponents of conservation would also be waging wars for pangolins (Phataginus and Smutsia in Africa), the most trafficked mammal in the world. Many conservation organizations are working to conserve pangolins but the interventions pale in comparison to the spectacle that rhino poaching has elicited. The attention on rhino is captured by a ranger who notes "a large part of the emphasis in rhino is because it is part of the megafauna that drives the tourism industry. If this was a duiker in Congo, do you think people would be going out armed with bulletproof vests to protect it?." The spectacularization of rhino conservation, in which 'humanity must come together' "belies the profound acts of differentiation-both among non-human species, between human populations, and within particular non-human species" (Biermann and Anderson, 2017: 5).

Furthermore, in Southern Africa, it has been argued that whites fashioned a deep connection with 'African' environments which allowed them to disengage from their black neighbors (Hughes, 2010). So, in some sense it is not a surprise that conservation institutions value rhino as a commodity more than black lives. What this article has shown, however, is that these interventions mask the value judgments that culminate in differential exposure to vulnerabilities. That is, the choice to intervene in rhino life even if to extract more profit from it, is also value laden. In the same vein the choice not to intervene in black lives beyond creating environmental subjects — is also value-laden. As shown, private conservation is prepared to wage wars to protect rhino, and to lobby international celebrities and countries, but fails to simply remunerate black laborers enough to meet their social reproductive needs while simultaneously depending on the unpaid social reproductive activities occurring in villages (Thakholi, 2021). Fundamentally this shows that the 
wildlife economy in South Africa is a microcosm of a capitalist order that has always depended on and reinforced human difference consistently along racial lines (Mbembe, 2017). Conservation of biodiversity takes this a step further by also creating a hierarchy in which wildlife is valued more than black workers.

While this analysis concentrated on human and non-human life forms, at an abstract level, interventions in some life forms, occupying certain geographical areas will necessarily make those landscapes viable for certain forms of life. Similarly, 'non-intervention' in other life forms occupying other places will render life more difficult, if not untenable in those landscapes (see Hawthorne, 2019). This is consistent with McIntyre and Nast (2011: 1466) who argue that the emergence of capitalism, from the separation of producers from their means of subsistence, was inscribed with "racially ontologized hierarchies of space, which permitted the hyper exploitation of certain (colorized) bodies and lands, but not others" [italics in original]. Thus, the spatial implications of the biopolitics of private conservation, that is, valuing wildlife while exposing black conservation labor to harm, are twofold. First, promoting wildlife through interventions such as those discussed in this article reinforces private nature reserves as viable landscapes supporting the lives of reserve owners, tourists, flora and fauna. Secondly, non-intervention in communities adjacent to private nature reserves, results in these landscapes unable to support viable lives and livelihoods. Biopolitics is thus spatial, as this article has shown. Sectors that are not as visually striking as extractive industries also make value judgements about life, and these decisions ultimately manifest in space.

\section{Bibliography}

't sas-Rolfes, M. 1990. The economics of rhino extinction. Endangered Wildlife 2.

Agrawal, A. 2005. Environmentality: community, intimate government, and the making of environmental subjects in Kumaon, India. Current Anthropology 46(2), 161-190.

Bakker, K. 2005. Neoliberalizing nature? Market environmentalism in water supply in England and Wales. Annals of the Association of American Geographers 95(3), 542-565. https://doi.org/10.1111/j.14678306.2005.00474.x

Biermann, C. and Anderson, R. M. 2017. Conservation, biopolitics, and the governance of life and death. Geography Compass 11(10), 1-13. https://doi.org/10.1111/gec3.12329

Biermann, C. and Mansfield, B. 2014. Biodiversity, purity, and death: conservation biology as biopolitics. Environment and Planning D: Society and Space 32(2), 257-273. https://doi.org/10.1068\%2Fd13047p

Biggs, D. Courchamp, F. Martin, R. et al. 2013. Legal trade of Africa's rhino horns. Science 339(6123), 1038-1039.

Büscher, B. 2018. From Biopower to ontopower? Violent responses to wildlife crime and the new geographies of conservation. Conservation and Society 16(2), 157-169.

Büscher, B. and Arsel, M. 2012. Introduction: Neoliberal conservation, uneven geographical development and the dynamics of contemporary capitalism. Tijdschrift Voor Economische En Sociale Geografie 103(2),129-135.

Büscher, B., Koot, S. and Thakholi, L. 2021. Fossilized conservation, or the deep unsustainability of saving nature in South Africa. Environment and Planning E: Nature and Space. In Press

Carruthers, J. 2008. 'Wilding the farm or farming the wild'? The evolution of scientific game ranching in South Africa from the 1960 s to the present. Transactions of the Royal Society of South Africa 63(2),160-181.

Castree, N. 2003. Commodifying what nature? Progress in Human Geography 27(3), 273-297.

Castree, N. 2008. Neoliberalising nature: processes, effects, and evaluations. Environment and Planning A: Economy and Space 40(1), 153-173.

Cavanagh, C. 2014. Biopolitics, environmental change, and development studies. Forum for Development Studies 41(2), 273-294.

Cavanagh, C. 2018. Political ecologies of biopower: diversity, debates, and new frontiers of inquiry. Journal of Political Ecology 25(1), 402-425. https://doi.org/10.2458/v25i1.23047 
Cavanagh, C. and Benjaminsen T. A. 2015. Guerrilla agriculture? A biopolitical guide to illicit cultivation within an IUCN category ii protected area. The Journal of Peasant Studies 42(3-4), 725-745. https://doi.org/10.1080/03066150.2014.993623

Clements, H.S. Knight, M. Jones, P. and Balfour, D. 2020. Private rhino conservation: Diverse strategies adopted in response to the poaching crisis. Conservation Letters 13(6), 1-8.

Collins, A. Cox, C. and Marire, J. 2020. On the judicial annulment of the 'domestic' trade moratorium in South African rhinoceros horn: A law and economics perspective. European Journal of Law and Economics 49(3), 361-372. https://doi.org/10.1007/s10657-020-09648-4

Crookes, D. J. and Blignaut, J. N. 2015. Debunking the myth that a legal trade will solve the rhino horn crisis: a system dynamics model for market demand. Journal for Nature Conservation 28, 11-15. https://doi.org/10.1016/j.jnc.2015.08.001

Eikelboom JAJ, Nuijten R. J. M., Wang Y. X. G., et al. 2020. Will legal international rhino horn trade save wild rhino populations? Global Ecology and Conservation 23, 1-14. https://doi.org/10.1016/j.gecco.2020.e01145

Emslie, R. and Brooks, M. 1999. African Rhino: Status survey and conservation action plan. IUCN.

Emslie, R. Milliken, R. Talukdar, B. et al. 2019. African and Asian rhinoceroses - status, conservation and trade. A report from the IUCN Species Survival Commission (IUCN SSC) Rev. CoP17.

Fletcher, R. 2010. Neoliberal environmentality: towards a poststructuralist political ecology of the conservation debate. Conservation and Society 8(3), 171-181.

Fletcher, R. Dressler, W. H., Anderson, Z. R and Büscher, B. 2019. Natural capital must be defended: green growth as neoliberal biopolitics. The Journal of Peasant Studies 46(5), 1068-1095.

Foucault, M. 2003. Society must be defended. Picador.

Harvey, D. 2014. Seventeen contradictions and the end of capitalism. Oxford University Press.

Hawthorne, C. 2019. Black matters are spatial matters: Black geographies for the twenty-first century. Geography Compass 13(11), 1-13.

Heatherington, T. 2012. From ecocide to genetic rescue can technoscience save the wild? In Sodikoff, G. M. (Ed.), The anthropology of extinction: Essays on culture and species death (pp. 39-66). Indiana University Press.

Hübschle, A. 2016. A game of horns: Tansnational flows of rhino horn. PhD dissertation. International Max Planck Research School on the Social and Political Constitution of the Economy.

Hübschle, A. 2017. Fluid interfaces between flows of rhino horn. Global Crime 18(3), $198-217$. https://doi.org/10.1080/17440572.2017.1345680

Hughes, D. 2010. Whiteness in Zimbabwe: Race, landscape, and the problem of belonging. Palgrave Macmillan.

Kepe, T. 2009. Shaped by race: why 'race' still matters in the challenges facing biodiversity conservation in Africa. Local Environment 14(9), 871-878.

Koot, S. 2021. Enjoying extinction: philanthrocapitalism, jouissance, and 'excessive environmentourism' in the South African rhino poaching crisis. Journal of Political Ecology. 28(1), 804-822. https://doi.org/10.2458/jpe.2984

Labban, M. 2014. Against shareholder value: accumulation in the oil industry and the biopolitics of labor under finance. Antipode 46(2), 477-496. https://doi.org/10.1111/anti.12062

Lorenzini, D. 2021. Biopolitics in the time of Coronavirus. Critical Inquiry 47(S2), 40-45. https://doi.org/10.1086/711432

Lunstrum, E. 2018. Capitalism, wealth, and conservation in the age of security: the vitalization of the state. Annals of the American Association of Geographers 108(4),1022-37.

Marcatelli, M. and Büscher, B. 2019. Liquid violence: the politics of water responsibilisation and dispossession in South Africa. Water Alternatives 12(2), 760-773.

Mbembe, A. 2017. Critique of black reason. Duke University Press 
McIntyre, M. and Nast, H. J. 2011. Bio(necro)polis: Marx, surplus populations, and the spatial dialectics of reproduction and 'race'. Antipode 43(5), 1465-1488. https://doi.org/10.1111/j.1467-8330.2011.00906.x

Moodley, Y. Russo, M. Dalton, D.L. et al. 2017. Extinctions, genetic erosion and conservation options for the black rhinoceros (diceros bicornis). Scientific Reports 7(1). https://doi.org/10.1038/srep41417

Negri, A. 2008. Antonio Negri: The labor of the multitude and the fabric of biopolitics. Mediations 23(2), 825.

Neimark, B. Mahanty, S. Dressler, W. \& Hicks, C. 2020. Not just participation: the rise of the eco-precariat in the green economy. Antipode 52(2), 496-521. https://doi.org/10.1111/anti.12593

Robinson, C. 1983. Black Marxism. Zed.

Rose, J. 2021. Biopolitics, essential labor, and the political-economic crises of COVID-19. Leisure Sciences 43(1-2), 211-217.

Snijders, D. 2015. Shifting species in South Africa wildlife policy, rural consequences. PhD dissertation. Vrije Universiteit Amsterdam.

Stats SA. 2019. Inequality trends in South Africa: A multidimensional diagnostic of inequality. Department of Statistics South Africa.

Taylor, A. Balfour, D. Brebner, D.K et al. 2017. Sustainable rhino horn production at the pointy end of the rhino horn trade debate. Biological Conservation 216, 60-68. https://doi.org/10.1016/j.biocon.2017.10.004

Thakholi, L. 2021. Conservation labour geographies: Subsuming regional labour into private conservation spaces in South Africa. Geoforum 123, 1-11. https://doi.org/10.1016/j.geoforum.2021.04.019

Wieckardt, C.E. Koot, S. and Karimasari, N. 2020. Environmentality, green grabbing, and neoliberal conservation: the ambiguous role of ecotourism in the green life privatised nature reserve, Sumatra, Indonesia. Journal of Sustainable Tourism, https://doi.org/10.1080/09669582.2020.1834564 